\title{
High arsenic enrichment in water and soils from Sambayourou watershed - Burkina Faso (West Africa)
}

\author{
Kagambega Nicolas ${ }^{1,2,3,}$, , Sawadogo Sayouba ${ }^{2}$, Gordio Ardjima ${ }^{2}$ \\ ${ }^{1}$ Department of mining engineering, Higher National School of Engineers of Fada (ENSI-F), Fada, Burkina Faso \\ ${ }^{2}$ Department of earth sciences, University of Ougadougou, (UO), Ouagadougou, Burkina Faso \\ ${ }^{3}$ Civil and Water Engineering Department, Sciences and Engineering Faculty, University of Laval (UL), Quebec, Canada
}

\section{Email address:}

kaninicolas@yahoo.fr (Kagambega N.)

\section{To cite this article:}

Kagambega Nicolas, Sawadogo Sayouba, Gordio Ardjima. High Arsenic Enrichment in Water and Soils from Sambayourou Watershed Burkina Faso (West Africa). International Journal of Environmental Monitoring and Analysis. Special Issue: Environmental Science and Treatment Technology. Vol. 2, No. 6-1, 2014, pp. 6-12. doi: 10.11648/j.ijema.s.2014020601.12

\begin{abstract}
Sambayourou is one of the main tributary of Mouhoun River in southwest Burkina Faso. Its watershed is part of area affected by mining operations from Poura gold mine in 80s. Investigations on surface water, ground-water and soil from Sambayourou watershed reveal that enormous volume of mine wastes from Poura old gold mine is causing acid mine drainage (AMD). This latter is characterized by a red-brick color, a low pH (2.9) and high contents of arsenic and heavy metals: arsenic (753 ppm), iron (4948 ppm), zinc (51 ppm), copper (38 ppm), cobalt (7 ppm) and lead (4 ppm). The oxidation and acidification of the mine wastes have also resulted in the pollution of some groundwater with concentrations of arsenic and lead beyond acceptable standards. Arsenic is the most polluting element of surface water and ground-water. Concerning ground-water contamination, arsenic come from both mine wastes and host rocks. To assess soil contamination, geo-accumulation indexes (Igeo) and enrichment factor (EF) are used. The use of the index of geo-accumulation is based on seven descriptive classes for increasing geo-accumulation index values. The different values of enrichment factor are divided into five groups corresponding to five categories of contamination. According to geo-accumulation values, the soil in Sambayourou watershed is strongly contaminated by arsenic. This situation is confirmed by enrichment factor which indicates a very high enrichment in arsenic. The very high enrichment in arsenic can derive from erosion of host rocks of ores mineralization which contain sulfide minerals as arsenopyrite (FeAsS) and/or from pedogenesis processes. However, mine wastes are assumed to be the main sources of arsenic contamination of soil in Sambayourou watershed.
\end{abstract}

Keywords: Arsenic Enrichment, Acid Mine Drainage, Heavy Metals, Environment, Burkina Faso

\section{Introduction}

Sambayourou, "Petit Balé" and "Grand Balé" are tributaries of Mouhoun which is the main river in southwestern Burkina Faso. Some of these tributaries as Sambayourou drains the site of the old gold mine at Poura. This gold mine was the first industrial mine in Burkina Faso which began operating in the 80s and ended in 1999. Fifteen (15) years after its closure, millions of tons of mine waste (tailings, waste rock) are always stored and exposed to water and weathering. What might generate impacts on the receiving environment and can also cause potential health risks of riparian communities. Apart from gold panning the majority of the population depends on agriculture and livestock breeding. Therefore, contamination of soil and water (ground and surface) can lead to health problems for both animals and humans through the food chain. In fact, the storage of these wastes has a direct effect on local ecosystems due to the loss of plant and animal communities living in the area in question [1]. In addition, discharges from mineral deposits that contain sulfide minerals have a high potential to generate acid mine drainage which is one of the most important problems for local and regional ecosystems. Acid generation promotes the mobilization of contaminants such as heavy metals and other potentially harmful elements. Heavy metals are a group of highly toxic contaminants to humans, animals and aquatic life [2, 3]. Arsenopyrite (FeAsS) is a sulfo-iron arsenide commonly found in sulfide mineralization especially those operated for gold. With the phenomenon of acid mine drainage (AMD), arsenic in arsenopyrite and other minerals is dissolved. The dissolved arsenic can be absorbed by plants or accumulated in 
sediments. Arsenate, As (V) inhibits the synthesis of Adenosine triphosphate (ATP). Its similarity with the phosphate allows it to penetrate the metabolic pathways. Arsenite, As (III) in acid waters is more toxic to aquatic organisms. It reacts with thiol groups present on the actives sites of enzymes and proteins. Some organic arsenic compounds are fat soluble and therefore bio-accumulative. Another major impact of the AMD is the questioning of the use of water downstream of mining sites, such as drinking water, recreational bases, irrigation, fisheries and industrial water use as well as corrosion of mining infrastructure and equipment.

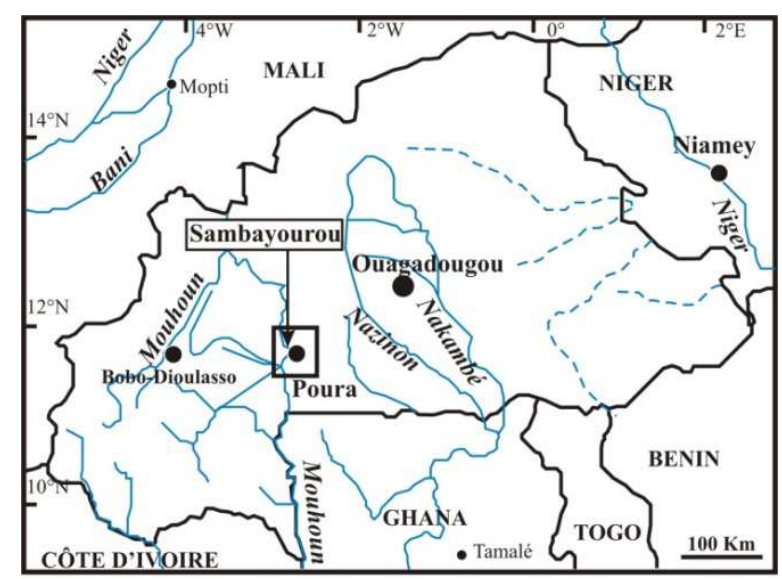

Figure 1. Location of the study area.

The aim of this study is to assess the impact of mine waste on the watershed of Sambayourou (Fig. 1): pollution of surface water, groundwater (wells and hand-pumped boreholes) and of soils then to identify contaminated areas as well as the elements (such as arsenic) responsible for the pollution.

\section{Methodology}

The methodology consisted in sampling of surface water, groundwater from hand-pumped boreholes, and soil in the watershed of Sambayourou. Each sample of water was directly filtered (with $0.45 \mu \mathrm{m}$ membrane pore diameter) into pre-acid-washed polyethylene bottles and acidified with ultra-pure $\mathrm{HNO}_{3}(\mathrm{pH}<2)$ for subsequent analyses of their major cations and trace element concentrations. The sampling was carried out under ultra-trace element conditions [4]. Thus, plastic glove were worn throughout the sampling, and contact with metallic tools was minimized. Samples were subsequently stored in double-zip lock bags.

Soil samples were collected. Each sample is a composite of three sub-samples collected from sampling sites located at the distance of 10-20 m from each other. About $3 \mathrm{~kg}$ of each sample was air-dried and sieved through a $2 \mathrm{~mm}$ stainless steel sieve, and homogenized. The fine fractions $(<2 \mathrm{~mm})$ were used for analysis.

Analyzes were performed in the laboratory "AcmeLabs" in Johannesburg" (South Africa).

\section{Results and Discussions}

\subsection{Sampling}

The different sampling sites through the watershed are reported in Figure 2.

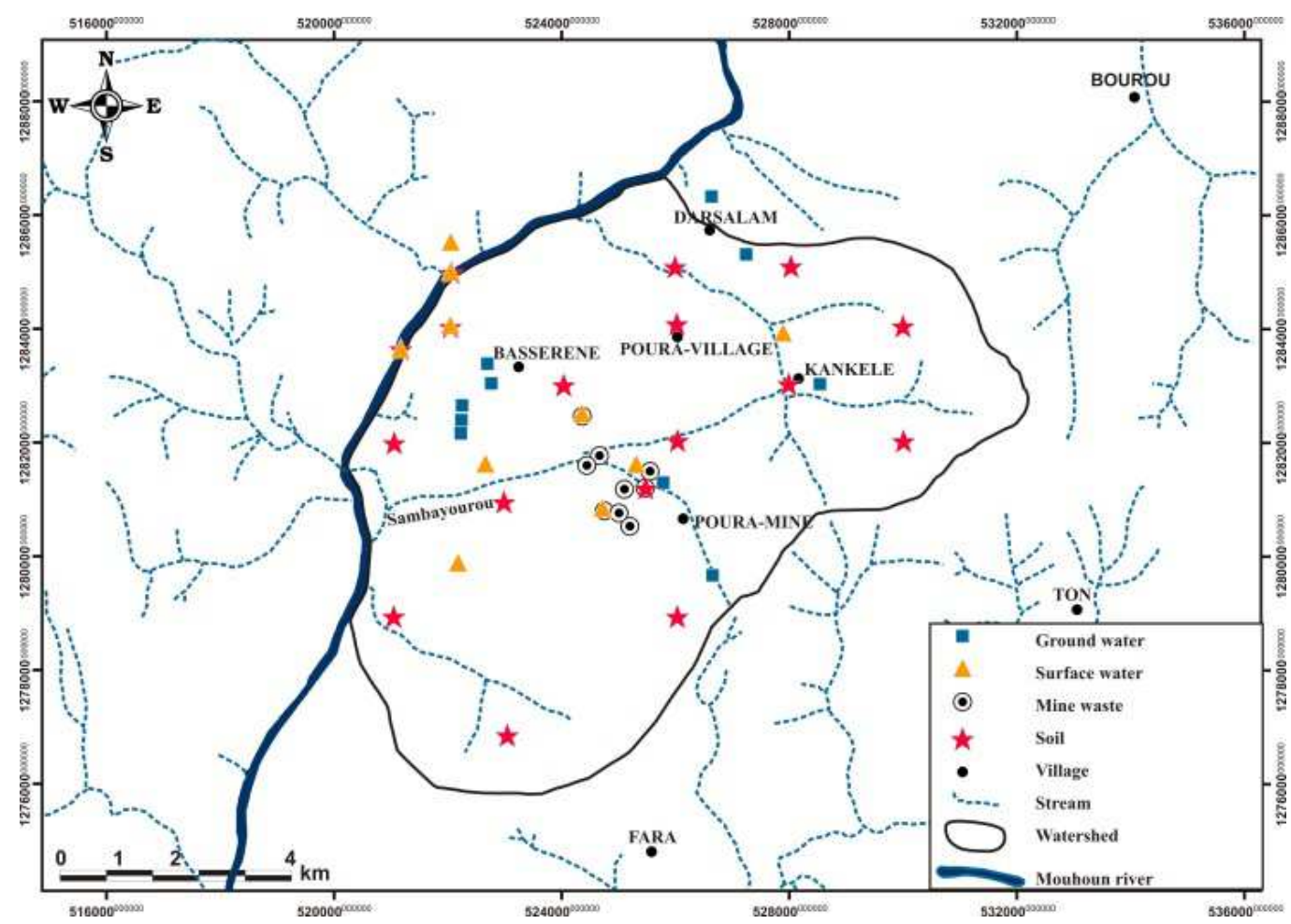

Figure 2. Location of sampling sites. 


\subsection{Surface Water}

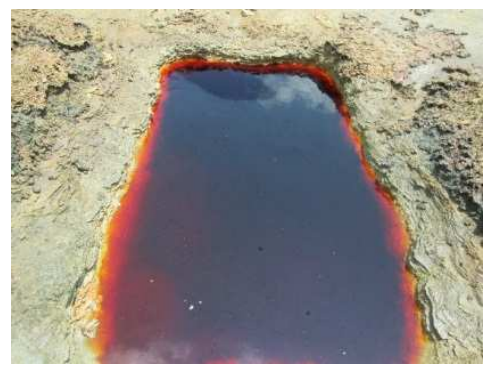

(a)

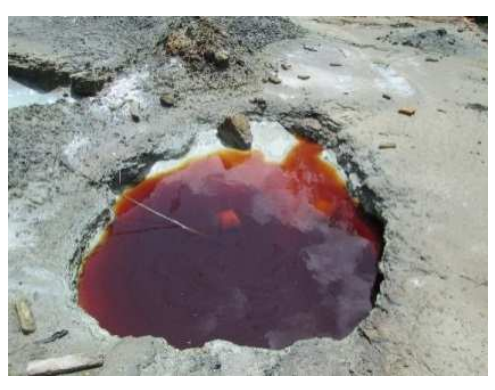

(b)

Figure 3. Surface water resulting from oxidation of mine wastes.

The surface water in some areas is characterized by a red-brick color (Fig. 3), a pH of 2.9 and a large amount of dissolved metals. Distribution of various elements in surface water is: iron (0.062-4948 ppm), arsenic (0.001-753 ppm), zinc (0.018-51 ppm), and lead (0.001-4 ppm). Sample SW13 has the highest levels for the different elements (Table 1). Indeed the acidification of the environment has the effect of promoting the solubilization of these elements and particularly of metals. This is the case of iron (4948 ppm), arsenic (753 ppm), zinc (51 ppm), copper (38 ppm), cobalt (7 ppm) and lead (4 ppm).

These results indicate oxidation and acidification levels which vary considerably from one place to another. Acid mine drainage is generally characterized by a $\mathrm{pH}$ value of about 4.5 . Acidification of the medium leads to the solubilization of these elements in the surface water and therefore in the environment.

Regarding the mineralogical composition, the mine wastes resulting from the mineralization of host rocks comprise pyrite (FeS), chalcopyrite ( $\mathrm{CuFeS})$, arsenopyrite (FeAsS). As a result, when the $\mathrm{pH}$ is sufficiently low $(\mathrm{pH}<4)$, ferric iron remains in solution, and thus playing the role of a highly reactive oxidant (the so-called indirect reaction). The indirect oxidation of pyrite produces more protons, and thus exacerbates acidification of the receiving environment [5-7].

This acid mine drainage and dissolved metals within the watershed can contaminate agricultural soils and water table but also convey in the Mouhoun River. The Mouhoun is the largest river in the region, which results in a vulnerability of aquatic living beings, animals and people.

\subsection{Ground-Water}

Ground-water is characterized (Table 2) by a pH close to neutrality (6.62-7.29) compared to the surface water. Analysis of results from Table 2 which summarizes the various physic-chemical parameters shows low $\mathrm{pH}(\mathrm{pH}=5.6)$ for the sample GW9. This is due to the geographical location of the sample GW9. Indeed it is at a close distance of the old mine and mine waste. It is therefore under the influence of surface water that is to say those phenomena from runoff and seepage from the mine. This $\mathrm{pH}$ also certify that beyond acidification and contamination of surface water, leachate from the different processes acid mine drainage may extend to deeper waters and have significant environmental consequences. The concentrations of various elements are below acceptable standards except for lead and arsenic. High levels of arsenic and lead are found in the drinking water. They exceed the standards accepted by the Burkina Faso (quality guidelines for drinking water, 2005) through the recommendations of the World Health Organization (WHO). This concerns the GW8 and GW10 samples for arsenic and GW1 for lead (Fig. 4). These elements have adverse effects to humans [8, 9]. Indeed, exposure to low levels of arsenic in the water may cause the risk of cancer of the skin while that a daily absorption of 3 to 6 $\mathrm{mg}$ or a dose of 70 to $180 \mathrm{mg}$ is a deadly poison. Regarding lead, chronic exposure may cause toxic effects on the central and peripheral nervous systems, reproductive disorders, kidney failure and encephalopathy. Arsenic and lead found in the groundwater may come in part from the migration of these elements after solubilization following oxidation of arsenopyrite $(\mathrm{FeAsS})$ and galena $(\mathrm{PbS})$ from mine wastes and to lower $\mathrm{pH}$ but also from the host rock of groundwater which have the same mineralogical composition.
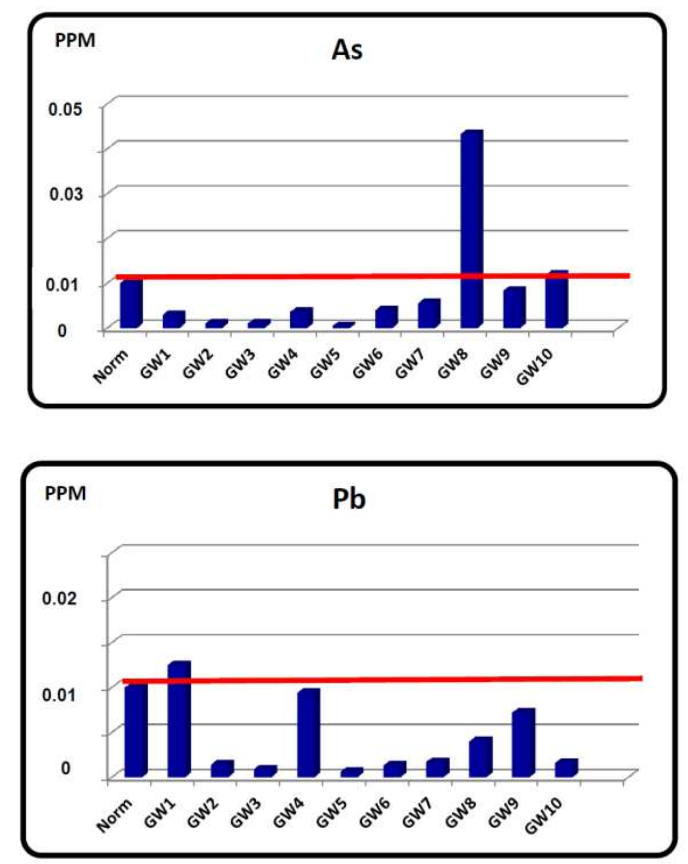

Figure 4. Levels of lead and arsenic above the accepted standards from Burkina Faso (after WHO) in certain drinking water. 
Although the oxidation of wastes and water contamination (surface and groundwater) are not yet widespread throughout the watershed, the effects are already significant and problematic.

Table 1. Physical parameters and levels of some potentially harmful elements in surface water samples.

\begin{tabular}{|c|c|c|c|c|c|c|c|c|c|c|c|}
\hline Element & pH & As & Cd & Co & $\mathrm{Cr}$ & $\mathrm{Cu}$ & $\mathrm{Fe}$ & $\mathrm{Hg}$ & $\mathrm{Ni}$ & $\mathbf{P b}$ & $\mathbf{Z n}$ \\
\hline Unit & & ppm & ppm & ppm & ppm & ppm & ppm & ppm & ppm & ppm & ppm \\
\hline$* \mathbf{L D}$ & & 0.0005 & 0.00005 & 0.00002 & 0.0005 & 0.0001 & 0.01 & 0.0001 & 0.0002 & 0.0001 & 0.0005 \\
\hline SW1 & 6.88 & 0.003 & $<\mathrm{LD}$ & 0.017 & 0.001 & 0.007 & 0.518 & $<\mathrm{LD}$ & 0.003 & 0.002 & 0.245 \\
\hline SW2 & 6.94 & 0.004 & $<\mathrm{LD}$ & 0.017 & 0.001 & 0.007 & 0.104 & $<\mathrm{LD}$ & 0.002 & 0.003 & 0.130 \\
\hline SW3 & 8.59 & 0.056 & $<\mathrm{LD}$ & 0.012 & $<\mathrm{LD}$ & 0.006 & 0.062 & $<\mathrm{LD}$ & 0.002 & 0.006 & 0.136 \\
\hline SW4 & 6.74 & $<\mathrm{LD}$ & $<\mathrm{LD}$ & 0.014 & 0.001 & 0.010 & 0.373 & $<\mathrm{LD}$ & 0.044 & 0.005 & 0.076 \\
\hline SW5 & 6.41 & 0.002 & $<\mathrm{LD}$ & 0.014 & 0.001 & 0.006 & 0.521 & $<\mathrm{LD}$ & 0.004 & 0.004 & 0.270 \\
\hline SW7 & 6.68 & $<\mathrm{LD}$ & $<\mathrm{LD}$ & 0.015 & 0.001 & 0.006 & 0.389 & $<\mathrm{LD}$ & 0.002 & 0.001 & 0.162 \\
\hline SW8 & 6.49 & 0.004 & $<\mathrm{LD}$ & 0.016 & $<\mathrm{LD}$ & 0.005 & 0.098 & $<\mathrm{LD}$ & 0.002 & 0.001 & 0.131 \\
\hline SW9 & 7.34 & 0.007 & $<\mathrm{LD}$ & 0.012 & 0.001 & 0.006 & 0.091 & $<\mathrm{LD}$ & 0.002 & 0.001 & 0.151 \\
\hline SW10 & 5.15 & 0.111 & $<\mathrm{LD}$ & 0.015 & 0.002 & 0.006 & 0.256 & $<\mathrm{LD}$ & 0.006 & 0.004 & 0.501 \\
\hline SW11 & 5.87 & 0.001 & $<\mathrm{LD}$ & 0.014 & 0.001 & 0.008 & 0.413 & $<\mathrm{LD}$ & 0.007 & 0.001 & 0.250 \\
\hline SW12 & 5.30 & 0.048 & 0.0002 & 0.016 & 0.009 & 0.011 & 9.314 & $<\mathrm{LD}$ & 0.010 & 0.012 & 0.490 \\
\hline SW13 & 2.90 & 753.710 & 0.700 & 7.429 & 1.329 & 38.924 & 4948.079 & $<\mathrm{LD}$ & 13.982 & 4.000 & 51.413 \\
\hline
\end{tabular}

*LD : Limit of detection

Table 2. Physical parameters and levels of some potentially harmful elements in ground water samples.

\begin{tabular}{|c|c|c|c|c|c|c|c|c|c|c|c|}
\hline Element & $\mathbf{p H}$ & As & Cd & Co & $\mathrm{Cr}$ & $\mathbf{C u}$ & $\mathbf{F e}$ & Hg & $\mathbf{N i}$ & $\mathbf{P b}$ & Zn \\
\hline Unit & & ppm & ppm & ppm & ppm & ppm & ppm & ppm & ppm & ppm & ppm \\
\hline$*$ LD & & 0.0005 & 0.00005 & 0.00002 & 0.0005 & 0.0001 & 0.01 & 0.0001 & 0.0002 & 0.0001 & 0.0005 \\
\hline GW1 & 6.81 & 0.003 & $<\mathrm{LD}$ & 0.012 & $<\mathrm{LD}$ & 0.005 & 0.052 & $<\mathrm{LD}$ & 0.002 & 0.013 & 0.222 \\
\hline GW2 & 6.84 & 0.001 & $<\mathrm{LD}$ & 0.012 & $<\mathrm{LD}$ & 0.005 & 0.074 & $<\mathrm{LD}$ & 0.001 & 0.001 & 0.185 \\
\hline GW3 & 6.62 & 0.001 & $<\mathrm{LD}$ & 0.013 & $<\mathrm{LD}$ & 0.006 & 0.069 & $<\mathrm{LD}$ & 0.001 & 0.001 & 0.183 \\
\hline GW4 & 6.80 & 0.004 & $<\mathrm{LD}$ & 0.013 & $<\mathrm{LD}$ & 0.005 & 0.031 & $<\mathrm{LD}$ & $<\mathrm{LD}$ & 0.009 & 0.183 \\
\hline GW6 & 6.90 & 0.004 & $<\mathrm{LD}$ & 0.012 & $<\mathrm{LD}$ & 0.004 & 0.016 & $<\mathrm{LD}$ & $<\mathrm{LD}$ & 0.001 & 0.681 \\
\hline GW7 & 6.92 & 0.006 & $<\mathrm{LD}$ & 0.013 & $<\mathrm{LD}$ & 0.006 & $<\mathrm{LD}$ & $<\mathrm{LD}$ & $<\mathrm{LD}$ & 0.002 & 0.149 \\
\hline GW8 & 6.90 & 0.043 & 0.001 & 0.011 & 0.001 & 0.004 & 0.027 & $<\mathrm{LD}$ & $<\mathrm{LD}$ & 0.004 & 0.506 \\
\hline GW9 & 5.60 & 0.008 & $<\mathrm{LD}$ & 0.013 & 0.001 & 0.005 & 0.116 & $<\mathrm{LD}$ & 0.002 & 0.007 & 0.205 \\
\hline GW10 & 7.29 & 0.012 & $<\mathrm{LD}$ & 0.016 & 0.001 & 0.006 & 0.086 & $<\mathrm{LD}$ & $<\mathrm{LD}$ & 0.002 & 0.276 \\
\hline
\end{tabular}

\subsection{Heavy Metals Contamination Levels in Soil}

To assess the level of soil contamination, the index of geo-accumulation $\left(\mathrm{I}_{\text {geo }}\right)$ of various elements is estimated [10, 11].

$$
\mathrm{I}_{\mathrm{geo}}=\log _{2}\left[\frac{\mathrm{Cm}}{1.5 \mathrm{XBV}}\right]
$$

$\mathrm{Cm}=$ concentration of a given element in the tested soil;

$\mathrm{BV}=$ concentration of the element in the Earth's crust; the background values (background value) $[12,13]$.

$1.5=$ a constant accounting for fluctuations in the content of a given substance in the environment. The use of the index of geo-accumulation is based on seven descriptive classes for increasing Igeo values (Table 3 ).

The enrichment factor allows distribution of the degree of contamination and to understand the distribution of anthropogenic elements in the elements [14].

$$
\mathrm{EF}=\frac{\left({ }^{C_{m}} / C_{F e}\right)}{\left(B_{m} / B_{F e}\right)}
$$

Where $\mathrm{C}_{\mathrm{m}}$ is the metal content in the sediment; $\mathrm{C}_{\mathrm{Fe}}$ is the content of iron in the sediments; $\mathrm{B}_{\mathrm{m}}$ is the average grade of the metal in the earth's crust; $\mathrm{B}_{\mathrm{Fe}}$ is the average content of iron in the Earth's crust.

Table 3. Igeo classes with respect to soil quality.

\begin{tabular}{lll}
\hline $\mathbf{I}_{\text {geo }}$ Value & $\mathbf{I}_{\text {geo }}$ Class & Designation of soil quality \\
\hline$>5$ & 6 & Extremely contaminated \\
$4-5$ & 5 & Strongly to extremely contaminated \\
$3-4$ & 4 & Strongly contaminated \\
$2-3$ & 3 & Moderately to strongly contaminated \\
$1-2$ & 2 & Moderately contaminated \\
$0-1$ & 1 & Uncontaminated to moderately contaminated \\
0 & 0 & Uncontaminated \\
\hline
\end{tabular}

Table 4. Enrichment categories based on EF values.

\begin{tabular}{ll}
\hline EF Value & Enrichment levels \\
\hline $\mathrm{EF}<2$ & Low enrichment \\
$2 \leq \mathrm{EF}<5$ & Moderate enrichment \\
$5 \leq \mathrm{EF}<20$ & Considerable enrichment \\
$20 \leq \mathrm{EF}<40$ & Highly enriched \\
$\mathrm{EF} \geq 40$ & Very highly enriched \\
\hline
\end{tabular}

Iron $(\mathrm{Fe})$ is a major component of the phenomenon of acid 
mine drainage, it is chosen as the normalizing factor for the determination of EF values. Iron is an element widely used reference for the calculation of the distribution of anthropogenic elements [15]. The different values of EF are divided into five (5) groups corresponding to five (5) categories of contamination [14] as indicated in table 4.

Table 5. Igeo and EF values of some elements in soil

\begin{tabular}{|c|c|c|c|c|c|c|c|c|c|c|c|c|c|c|}
\hline \multirow{2}{*}{$\begin{array}{l}\text { Element } \\
\text { Value }\end{array}$} & \multicolumn{2}{|c|}{ Arsenic } & \multicolumn{2}{|c|}{ Chromium } & \multicolumn{2}{|c|}{ Cobalt } & \multicolumn{2}{|c|}{ Copper } & \multicolumn{2}{|l|}{ Lead } & \multicolumn{2}{|c|}{ Nickel } & \multicolumn{2}{|l|}{ Zinc } \\
\hline & Igeo & EF & Igeo & EF & Igeo & EF & Igeo & EF & Igeo & EF & Igeo & EF & Igeo & $\mathbf{E F}$ \\
\hline S1 & -0.24 & 1.17 & 0.84 & 0.93 & 1.04 & 1.39 & 1.20 & 0.85 & 0.90 & 0.95 & 0.51 & 0.58 & -0.03 & 0.48 \\
\hline S2 & 2.17 & 201.60 & 0.83 & 0.61 & 1.38 & 2.04 & 1.52 & 1.20 & 1.51 & 2.65 & 0.58 & 0.46 & 0.64 & 1.48 \\
\hline S3 & 0.64 & 7.70 & 1.04 & 1.29 & 1.03 & 1.19 & 1.29 & 0.90 & 0.47 & 0.31 & 0.69 & 0.75 & -0.18 & 0.29 \\
\hline S4 & 0.51 & 4.96 & 1.27 & 1.92 & 1.24 & 1.66 & 1.26 & 0.74 & 0.57 & 0.34 & 1.00 & 1.34 & 0.05 & 0.44 \\
\hline S5 & -0.65 & 0.96 & 0.52 & 0.96 & 0.51 & 0.87 & 0.70 & 0.58 & 0.66 & 1.17 & -0.06 & 0.33 & -0.63 & 0.25 \\
\hline S6 & 0.20 & 4.23 & 0.95 & 1.58 & 1.05 & 1.87 & 1.07 & 0.83 & 0.49 & 0.49 & 0.69 & 1.15 & -0.27 & 0.36 \\
\hline S7 & 0.97 & 22.92 & 0.87 & 1.21 & 1.08 & 1.87 & 1.10 & 0.84 & 0.51 & 0.49 & 0.19 & 0.34 & -0.44 & 0.23 \\
\hline S8 & 0.71 & 8.31 & 1.60 & 4.32 & 1.17 & 1.51 & 1.20 & 0.69 & 0.40 & 0.25 & 1.25 & 2.55 & -0.15 & 0.29 \\
\hline S9 & 1.46 & 40.47 & 0.97 & 0.88 & 1.21 & 1.47 & 1.32 & 0.79 & 1.03 & 0.92 & 0.46 & 0.36 & 0.39 & 0.87 \\
\hline S10 & 1.18 & 25.25 & 0.82 & 0.74 & 1.13 & 1,43 & 1.20 & 0.71 & 0.49 & 0.31 & 0.53 & 0.50 & 0.07 & 0.49 \\
\hline S11 & 1.67 & 21.48 & 1.58 & 1.15 & 1.31 & 0.59 & 1.45 & 0.34 & 1.30 & 0.55 & 0.48 & 0.12 & 0.19 & 0.18 \\
\hline $\mathrm{S} 12$ & 0.30 & 4.63 & 1.14 & 2.12 & 1.04 & 1.62 & 1.08 & 0.74 & 0.51 & 0.44 & 0.61 & 0.84 & -0.25 & 0.33 \\
\hline S13 & 0.93 & 22.96 & 0.74 & 0.99 & 1.09 & 2.12 & 1.10 & 0.91 & 0.51 & 0.53 & 0.30 & 0.47 & -0.40 & 0.27 \\
\hline S14 & 0.36 & 4.67 & 0.88 & 1.02 & 0.97 & 1.20 & 0.89 & 0.42 & 0.57 & 0.45 & 0.21 & 0.29 & -0.30 & 0.26 \\
\hline S15 & 0.30 & 4.42 & 0,76 & 0.84 & 0.91 & 1.14 & 0.98 & 0.56 & 0.44 & 0.36 & 0.35 & 0.43 & -0.36 & 0.24 \\
\hline
\end{tabular}

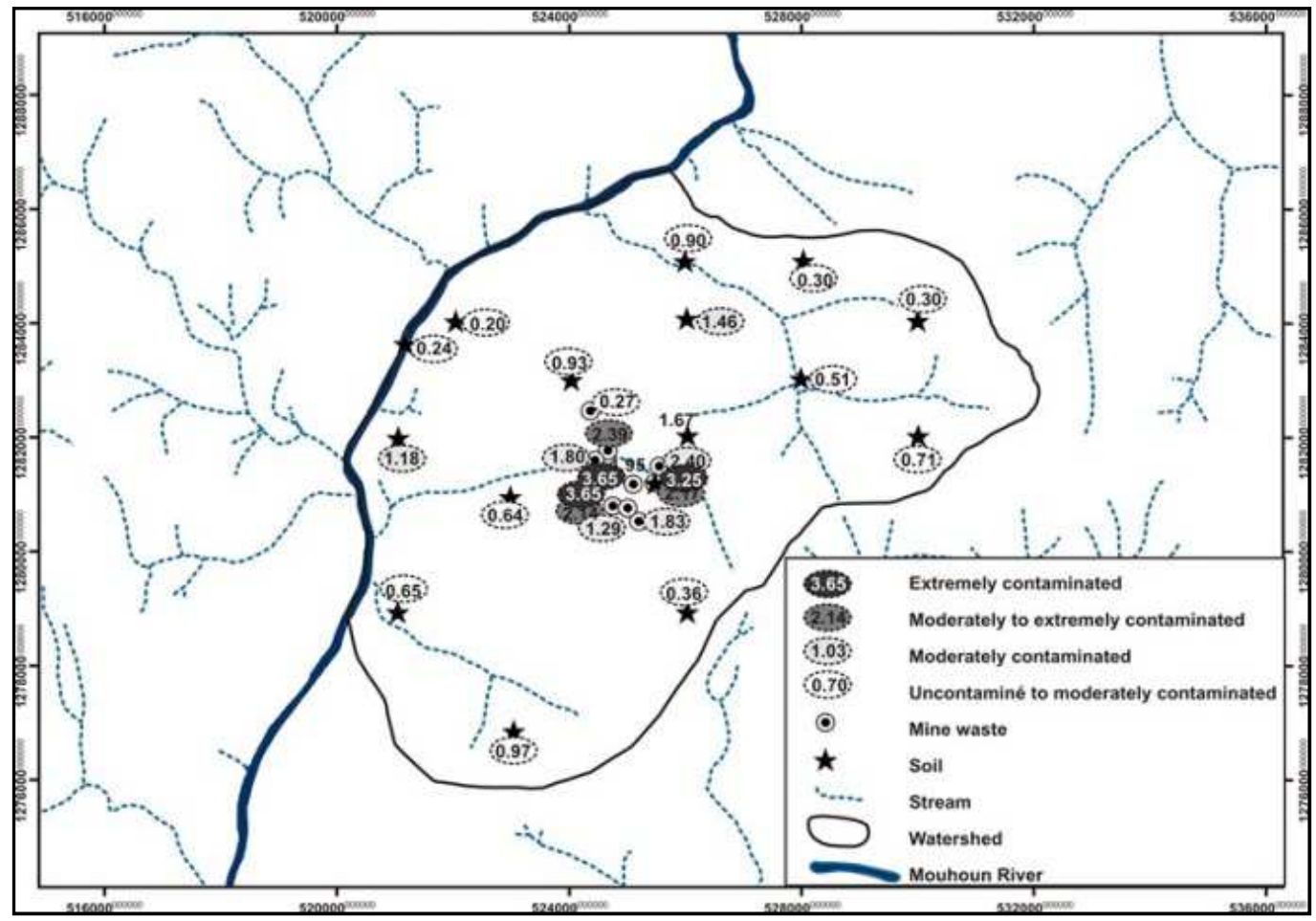

(a) 


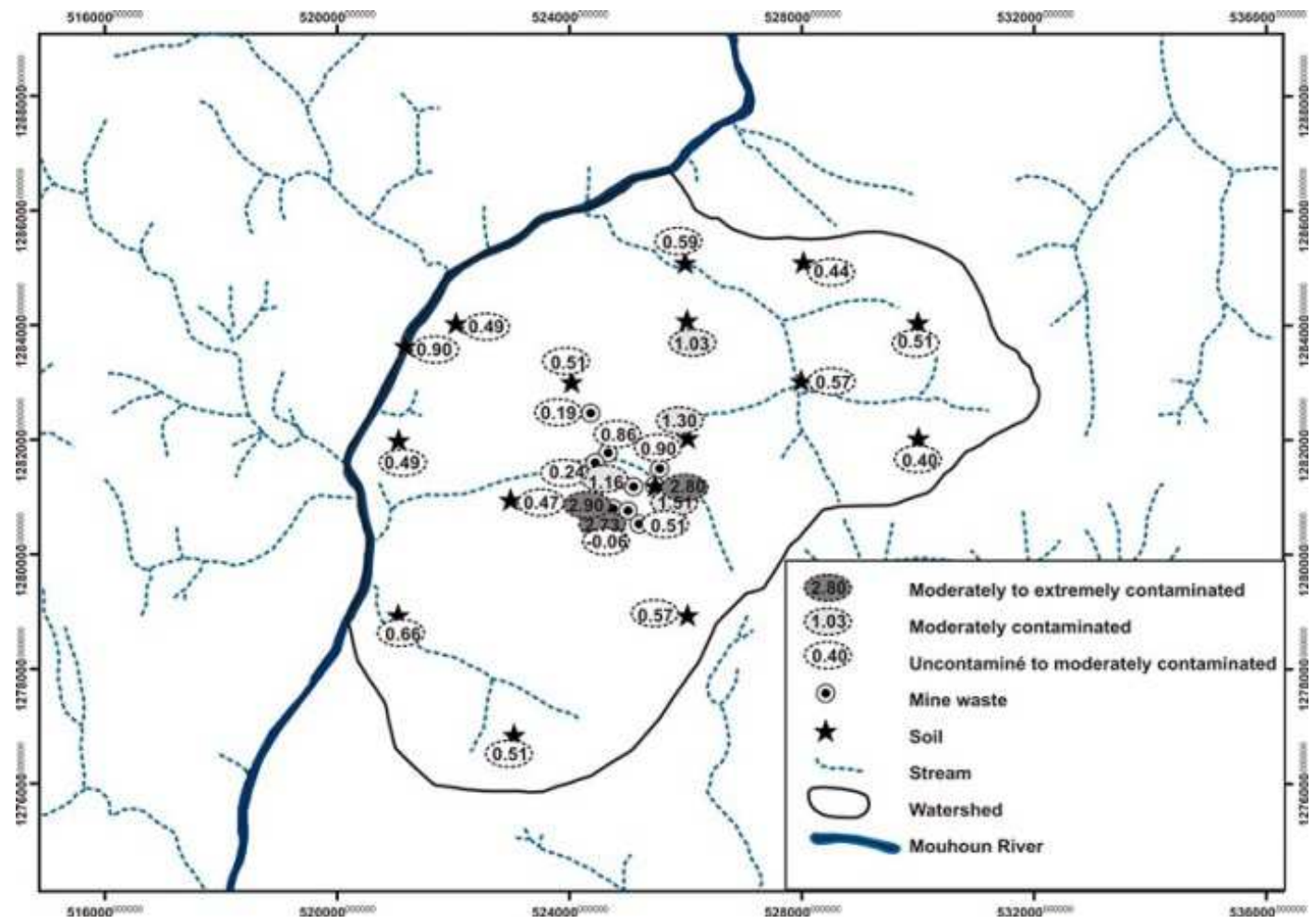

(b)

Figure 5. Distribution of geo-accumulation indexes (Igeo) values of arsenic (a) and lead (b).

According to Igeo values, soil inside the watershed is uncontaminated to moderately contaminated by all the elements reported in Table 5 (i.e. arsenic, chromium, cobalt, copper, lead, nickel, zinc); moderately contaminated by arsenic, chromium, cobalt, copper lead and to a lesser extent by nickel; moderately to strongly contaminated by only arsenic. These results show that contamination levels vary from one element to another and from one point to another within the watershed (Fig. 5). This situation can be attributed to the fact that the mine wastes have not undergone the same degree of oxidation in the watershed.

Concerning the enrichment factor, as out showed the index of geo-accumulation, the soil is considerably to very highly enriched in arsenic. However, it is low enriched in arsenic, chromium, cobalt, copper, lead, nickel and zinc on one hand, and moderately in arsenic, chromium, cobalt and lead in the other hand.

Contamination depends largely on the availability of elements. Arsenic, chromium, cobalt and lead are the most available elements; nevertheless arsenic appears to be the most polluting element which is known carcinogen. EF shows that their contents in soil are due to a supply. Several authors have reported arsenic contamination of soils and sediments related to mining operations (e.g. [15 - 17]. Reference [18] show that strong arsenic enrichments in sediments from Elqui watershed in Chile is not only industrial derived (mining operations), but also a major geological process, related to long-lived erosion of the As-rich epithermal ores and alteration zones.
Arsenic enrichment in Sambayourou watershed can be attributed to the mine wastes from Poura old gold mine. Ore zones and mainly those bearing sulfide minerals are often enriched in arsenic [19]. In fact gold exists in two forms at Poura: the first form is related to free gold or disseminated in quartz, and the second form concerns the association of gold and sulfide minerals: pyrite $(\mathrm{FeS})$, chalcopyrite $\left(\mathrm{CuFeS}_{2}\right)$ and arsenopyrite (FeAsS). So, arsenic can result from arsenopyrite which composes mine wastes with others minerals. In addition, the soil derives from the bedrock through erosion and pedogenesis processes. But according to the contamination levels i.e. Igeo indexes and enrichment factors values, sources of arsenic related to erosion and pedogenesis processes are assumed to be lower than those related to mine wastes stored during several years.

\section{Conclusions}

In Sambayourou watershed, a portion of mine wastes is oxidized and as result acid mine drainage with a red-brick color concerning surface water can be observed. In addition, acidification of surface water leads to high contents of heavy metals and arsenic. Ground-water which consists of hand-pumped boreholes and wells presents in some area high levels of arsenic and lead above accepted standards. In surface water and ground-water, arsenic appears as the most polluting element. Arsenic is assumed to derive from oxidation and acidification of mine wastes and from host rocks of ground-water. 
Soil is also contaminated by heavy metals and arsenic. As in the case of water pollution (surface water and ground-water), the soil is strongly contaminated by arsenic and the enrichment factor indicates a very high enrichment. Even if, erosion and pedogenesis processes can apply soil in arsenic, enrichment factor and oxidation/acidification of several tons of mine wastes are assumed to be the main source of arsenic contamination.

\section{Acknowledgements}

The authors would like to thank the "Programme Canadien des Bourses de la Francophonie" (PCBF) and the Canadian International Development Agency (CIDA).

We are grateful to Sida-UNESCO project (503RAF2000) for the support of this study. We are very grateful to the Newmont Company through its national manager in Burkina Faso Mr. Cyril KABRE. The authors also thank Mr. Salif Lamoussa KABORE, Burkinabe Minister in charge of Mines for permission to access and sampling.

\section{References}

[1] Aubertin, M., Bussière, B., Bernier, L. Environnement et gestion des rejets miniers, 2202a, manuel sur cédérom.

[2] Voet, E., Jeroen, B.G., Helias, A.U.H. Heavy metals: A problem solved. Methods and models to evaluate policy strategies for heavy metals. Kluwer Academic Publishers, 242 .

[3] Artignan, D., Cottard, F. Éléments à prendre en compte pour l'évaluation des impacts environnementaux dans l'élaboration d'un plan de prévention des risques miniers (PPRM). Rapport BRGM / RP -52049 (2003) - FR, 46p.

[4] Patterson, C.C., Settle, D,M., The reduction of orders of magnitude errors in lead analysis of biological materials and natural waters by evaluating and controlling the existent and source of industrial lead, handling, and analysis, Natl. Bureau Stand. Spec. 1976, Publ. 422, pp. 321-351.

[5] Kleimann, R.L.P., Crerar, D.A. Pacellil, R.R., Biogeochemistry of acid mine drainage and a method to control acid formation. Mining Engineering, 1981, pp. 300-304.

[6] Aubertin, M., Bussière, B., Bernier, L., Chapuis, R., Julien, M., Belem, T., Simon, R., Mbonimpa, M., Benzaazoua, M. La gestion des rejets miniers dans un context de développement durable et de protection de l'environnement. Congrès annuel de la société canadienne de genie civil, 2002, Article No. GE-045, Montréal, Canada.
[7] Bussière, B., Aubertin, M., Zagury, G., Potvin, R., Benzaazoua, M. Principaux defies et pistes de solution pour la restauration des aires d'entreposage de rejets miniers abandonnées, 2005.

[8] Winfield, M., Coumans, C., Kuyek, J.N., Meloche, F., Taylor, A. Sous la surface: une estimation de la valeur du soutien public aux mines de métaux au Canada. Support for the metal mining industry in Canada, 2002, 57p.

[9] Collon, P. Évolution de la qualité de l'eau dans les mines abandonnées du bassin ferrifère lorrain. De l'expérimentation en laboratoire à la modélisation in situ, Thèse de Doctorat de l'INPL, Nancy, 2003, 247p.

[10] Muller, G. Index of geo-accumulation in sediments of the Rhine River, Geological Journal, 1969, 2 (3), pp. 108-118.

[11] Krzysztof, L., Wiechula, D., Korns, I. Metal contamination of farming soils affected by industry, Environment International, 2003, 30, pp. 159-165.

[12] Levinson, A.A. Introduction to exploration geochemistry, second ed., 1974, the applied publ. Ltd., Wilnette Illinois.

[13] Lar, U.A., Ngozi-Chika, C.S., Ashano, E.C. Human exposure to lead and other potentially harmful elements associated with galena mining at New Zurak central Nigeria. Journal of African Earth Sciences, 2013, 84, pp. 13-19.

[14] Simex, S.A., Helz, G.R. Regional geochemistry of trace elements in Chesapeake Bay sediments. Environ. Geol., 1981, 3, pp. 315-323.

[15] Loska, K., Wiechula, D., Barska, B., Cebula, E., Chojnecka, A. Assessment of arsenic enrichment of cultivated soils in southern Poland, Polish journal of environmental studies Vol. 12, No 2(2003), pp. 187-192.

[16] Sutherland, R.A. Bed sediment-associated trace metals in an urban stream, Oahu, Hawaii, Environ. Geol., 2000, 39, pp. 611-626.

[17] Kim, C.S., Anthony, T.L., Goldstein, D., Rytuba, J.J. Windborne transport and surface enrichment of arsenic in semi-arid minig regions: examples from the Mojave desert, California, Aeolian Research, 2014, in press.

[18] Oyarzun, R., Lillo, J., Higueras, P., Oyarzun, J., Maturana, H. Strong arsenic enrichment in sediments from the Elqui watershed, Northern Chile: industrial (gold mining at El Indio Tambo district) vs. geologic processes. Journal of Geochemical Exploration 84 (2004), pp. 53-64.

[19] Smedley, P.L., Knudsen, J., Maiga, D. Arsenic in groundwater from mineralized Proterozoic basement rocks of Burkina Faso. Applied Geochemistry, 2007, 22, pp. 1074-1092. 